Portland State University

PDXScholar

5-23-1969

\title{
The Biological Properties of Pseudomonas aeruginosa Bacteriophage 7v
}

Shirley Phillips Schnider

Portland State University

Follow this and additional works at: https://pdxscholar.library.pdx.edu/open_access_etds

Part of the Biology Commons

Let us know how access to this document benefits you.

\section{Recommended Citation}

Schnider, Shirley Phillips, "The Biological Properties of Pseudomonas aeruginosa Bacteriophage 7v" (1969). Dissertations and Theses. Paper 771.

https://doi.org/10.15760/etd.771

This Thesis is brought to you for free and open access. It has been accepted for inclusion in Dissertations and Theses by an authorized administrator of PDXScholar. Please contact us if we can make this document more accessible: pdxscholar@pdx.edu. 
AN ABSTRACT OF THE THESIS OF Shirley PhIlifpa Schnider for the Master of Sclence in Blology presented May 23, 1969.

Title: The Blological Properties of Pseudomonas aerugLnosa Bacteriophage $7 \mathrm{~V}$.

APPROVED BY MEMBERS OF THE THESIS COMMITTEE:

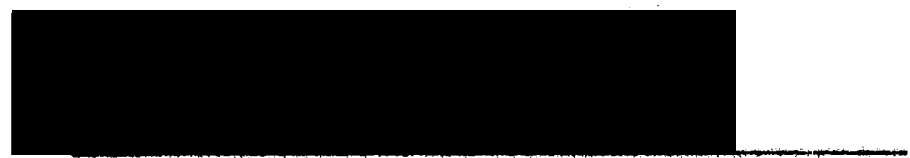

Ear1 Fisher, Jr., Chairman

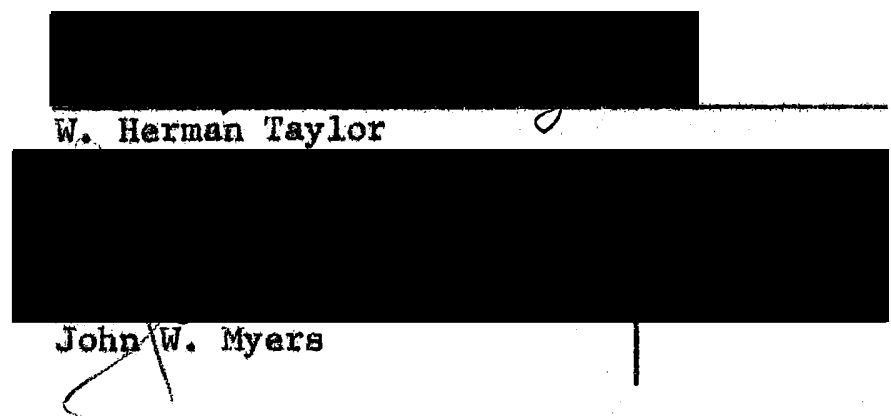

The present study was undertaken to define the standard conditions for growth of bactertophage $7 \mathrm{~V}$ on ita host Pseudomonas aeruginosa atrain PS-7 and to determine the factors which affect the quantity and quality of plaques in the plaque count assay, Observations from the single-step growth expertment and single-burst experiment are also Inoluded.

Plaque count assays were performed under vartous anvironmental conditions. Conditions were selected as "standard" if they ylelded: 1) relative maximum number of infective centers per ml of stock $7 \mathrm{~V}$ phage, 2) elear, haloed plaques at least $2.0 \mathrm{~mm}$ in diameter, and 3) reproductble assays Ifited only by the sampling error. 
Thes cond1tions ane:

1. Exeoh NGYE or NBYE agax for the growth

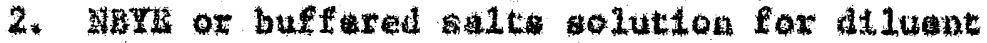

3. phy lalogicaliy young cello in the log phase betwean $1-5 \times 108$ bactoria/mi

4. atock and dituted tock suspentons stored at refrigarat ot temperaturos *

Adworption rate exportmente wheh measured both turdsorbed phage

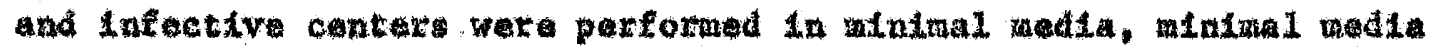

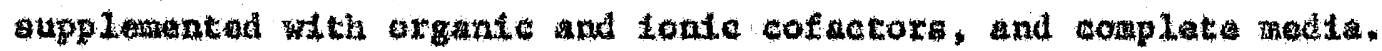

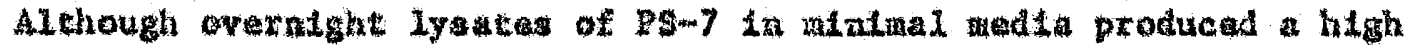
titer of phage, the rate of adsorption of phage $7 \mathrm{y}$ it $78-7$ a

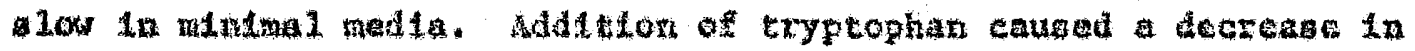
frea pha wthout a corresponding increase in infoutiva cantaro. Casamino acido plue exyptophan caused an Inorease in the veloct of

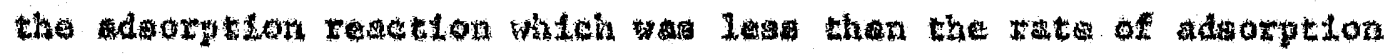

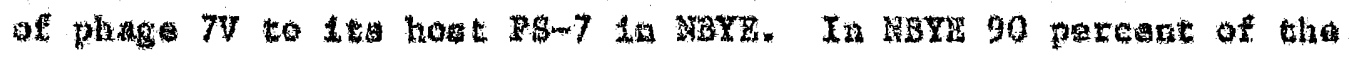

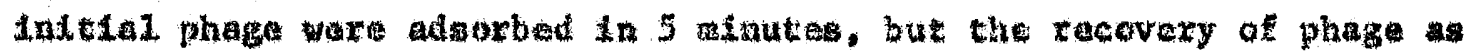

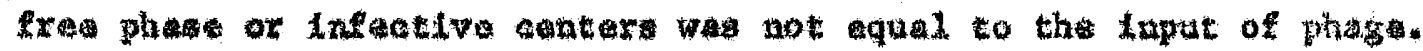

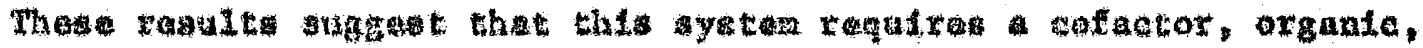

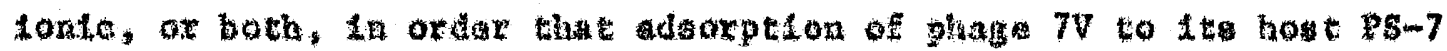

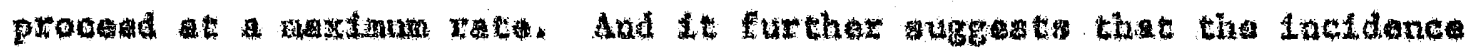

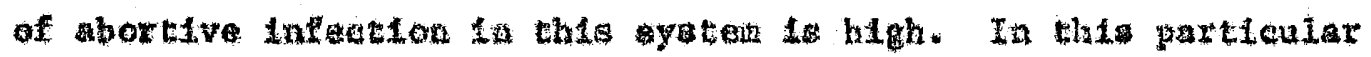

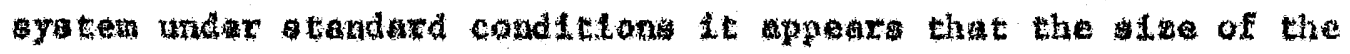

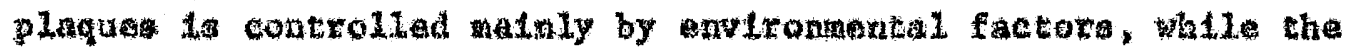
ralative number of plaquas to a chacuctartate of the aysten. 


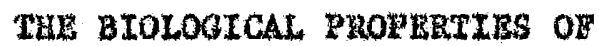

PSEUDOHONAS ASRUGINOSA BACTERIONHACE $7 \mathrm{~V}$

by

SHIRLEX PGILLIPS SCHEIDHR

A thes submitid in partial fulfiliment of the requix antic for the degree of

MASTER OF SCTZMCE

1 a

BIOLOGY

Portland State Universtty

1969 
TO THE OFEICE OF GRADUATE STUDIES:

The members of the Cominttee approve the thesis of Shirley Phillips Schnider presented May 23, 1969.

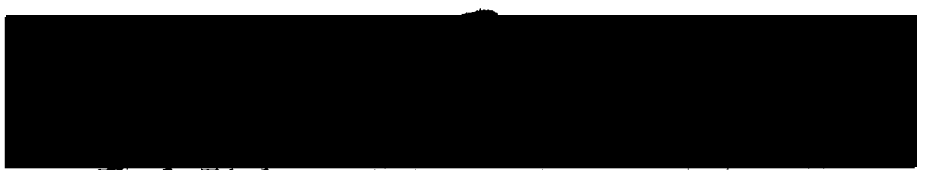

Earl Fisher, Jr., Chairman

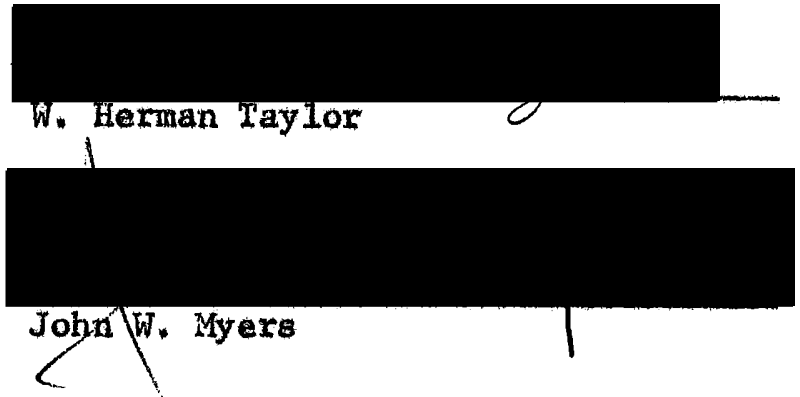

APPROVED:

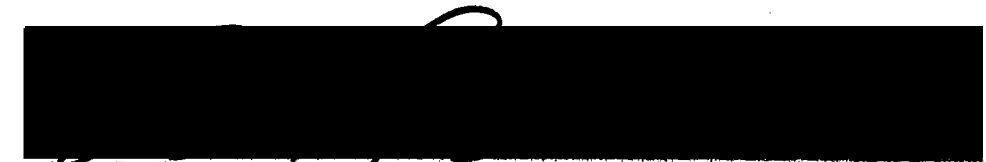

Ear1 Flshex, Jr., Head, Department of Biology

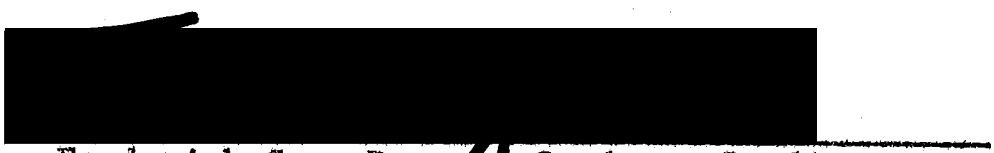

Frederick Cox, Dean 6 Graduate Studies

May 23, 1969 
TABLE OF CONTENTS

PAGE

LIST OF TABLES ....................... IV LIST OH FIGURES . . . . . . . . . . . . . . . . . . v INTRODUCTION . . . . . . . . . . . . . . . . . . . 1 MATERIALS AND METHODS . . . . . . . . . . . . . . . . 3

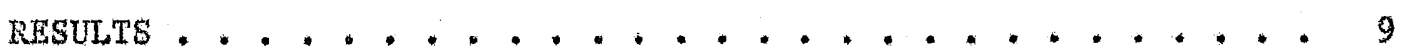

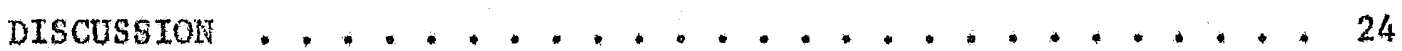
LITERATURE CTTED . . . . . . . . . . . . . 26 


\section{LIST OF TABLES}

TABLE

I Effect of Age of ABYE Plates on Plaque Number and Plaque \$1ze,............... 10

II The Rffect of Varying Concentrations of Calctum Ions on the Number of Viable Bacteria per ml and Pleque Forming Units per n1....... 12

III The Effect of Temperature and Dilution on the Rlaque Forming Ability of a Stock $7 \mathrm{~V}$ Phage in NBYE . . 13

IV Kineties of the Adsorption of Bacteriophage $7 \mathrm{~V}$ to Its Host PS-7 at Varlous Densities of Bactoria and Bacteriophage . . . . . . . . . . 16

V Iffect on Adsorption Rate Constant of Calcium and Sodiun Ions... . . . . . . . . . 17

VI Compartson of Plaque Count Assay on Complete and Chemically Defined Media . . . . . . . . 19

VII Effect of Cofactors on the Adsorption Rate of Phage $7 V$ to 1 ts Host PS-7 in Minimal Media ..... 21 


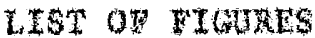

WOURE PAC

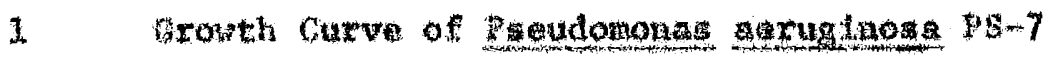

Correlated wth Adsorbance * . . . . . . . . 5

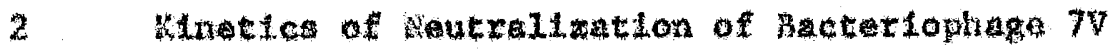

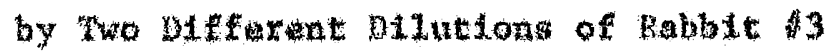

Antu-7V Serua , ..............., 7

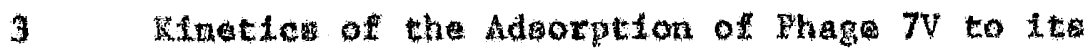

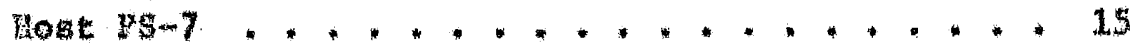

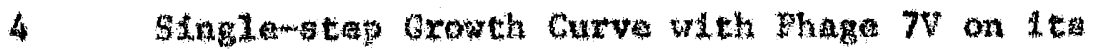

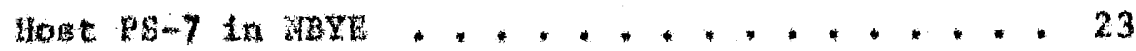


INTRODUCTION

In 1953 Lwoff asked, "whether or not the characters, temperate and virulent, are correlated with spectflc properties other than lygogentzation" (Lwoff, 1953), A virulent phage which differs from a temperate phage by one, or a few mutational steps, must also differ from this phage in the structure of at most a few clatrons and, therefore, In some recognizable morphological or biochenieal characteriatics.

Ten years later Feary (1963) reported the isolation of a bactex1ophage, designated $7 V$, which he postulated arose as a spontaneous mutation, or series of mutations, of a temperate phage lysogente for strain PS-7 of Pseudomonas aeruginoga. The temperate phage which gave rise to phage $7 \mathrm{~V}$ was not 1solated, probably because of the lack of gensitive Indicator stralns. On agar plates seeded with PS-7, phage $7 \mathrm{~V}$ produces clear, haloed plaques with no bacterial growth in the center, Indicating that phage $7 \mathrm{~V}$ is a virulent mutant unable to lysogenize 1 ts host PS-7. (Stent, 1963). In addition to plaque norphology, phage 7V also resembles the supervirulent $\mathrm{T}-2$ phage in s1ze, morphology, and chemical compositIon (Feary, 1963).

Coliphage T-2 is not 1ysogente. Upon entry into the bacterial ce11, it causes digtntegration and dispersal of the bacterial DNA within the first few minutes (stent, 1963). Other virulent mutants of

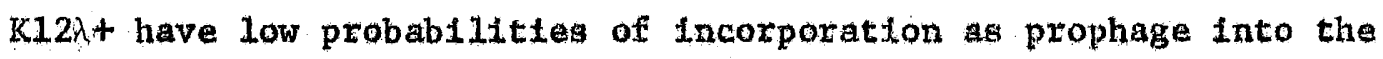

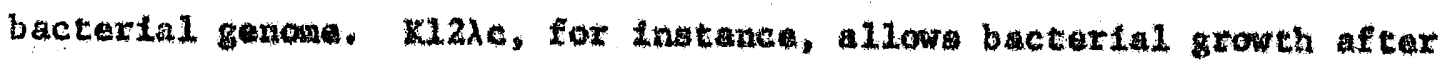
Infection and is virulent because it fall to produce repressor. 
(Stent, 1963).

Phage $7 \mathrm{~V}$ may resenble the supervirulent collphage $T-2$ in 1 ta mean of perpatuation; or, although physleally gimilar to $7-2$, it may resuble the moderate virulent $212 \lambda+$ phage, Should phage $7 v$ prove to be a muprvirulent mutant, it would be mean of tenting the genexalti of the models proposed on the bas is of work done wh the coliphage, and $1 \mathrm{t}$ may provide the mean of detemining vizulence characteristics whleh have oluded study in the coliphage systom *

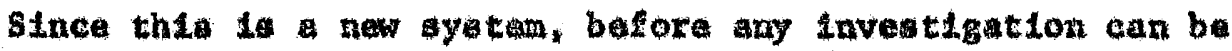
undartaken atandard aet of condtion mat frat bo definad. Whe

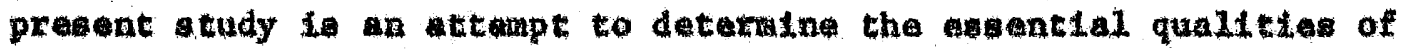
the plaque count abay leading to: 1) the maximum number of Infectivo canter:, 2) large, alear haloed plaques, and 3) a reproductble asagy 1indted only by the sampling arror. 


\section{MATERIALS AND MUTHZODS}

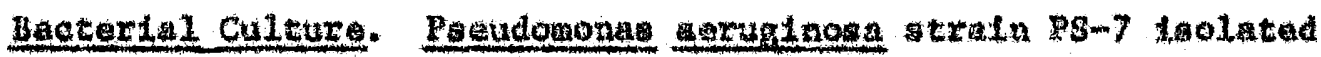
from an ocular lafection and malntalned by aral cranafex on tryptcase goy blood agax was provided by Jr. Barl FIsher, Jx. It was grown ln

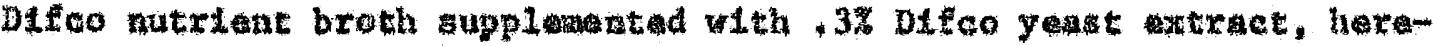
after called Motw; or the chentealiy defined mad1a, M-9 with $1 \%$

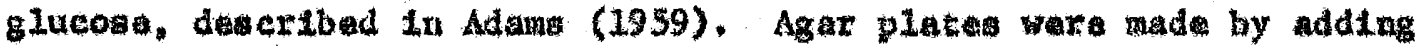

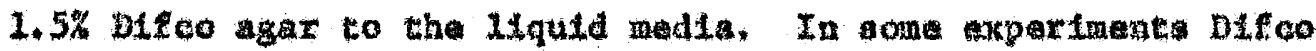

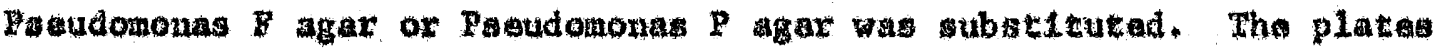
contalning approxiataly $30 \mathrm{ml}$ af agaz madia pax plate vere ineubatod at row temparature unth all surface molsture had avaporated. Culturas

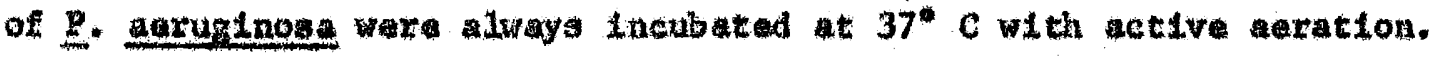
Bacter lophage $7 V$ Stogk. A saple $(0.1 \mathrm{~m})$ of an 18 hour culture

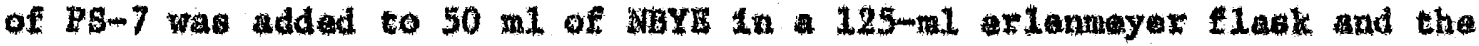
cultur was tneubated unt11 the bactartal denst ty radehed $2-4 \times 10^{8}$ bacterta per m. A previouly prepared and aceurately teereut tocic phage 7 was duded to obtain atro of on phage for every 400 to 500 bacterla, whe flak was atad and incubated at $37^{\circ}$ o with aration for 5 minuter. Two wl of this phage-bacterlal suapenoton was than added to

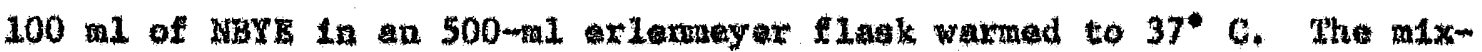
ture tro tneubated for 6 hours (Hook et al, 1946 and Plake, 1959). A drop of chloroform was added and the oumpenton was vigorous ly mitred and then centrifuged at $16,300 \times \mathrm{g}$ for 10 atnutev to remove debris. The lysate was than pased through corning alntared glase flicer to 
ramoy the romainiag particulate matter. Iach step of the puriffeation was assayed for plaque forming uate by the soft agar overlay plaque count aethod, attributed to Gratla, and deactbod in Adans (1959). The

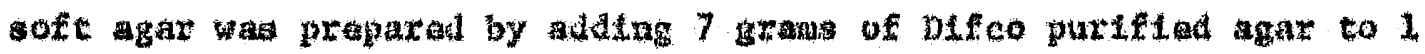

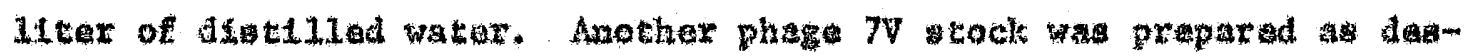

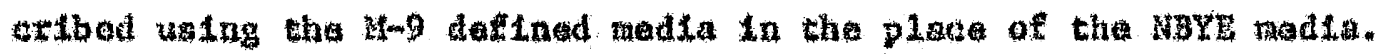

Asgay of 2S-7. A tample of a young broth cultuxa of PS-7 growing: In NBXI at $37^{\circ} 0$ with seration was removed and an aliquot placed

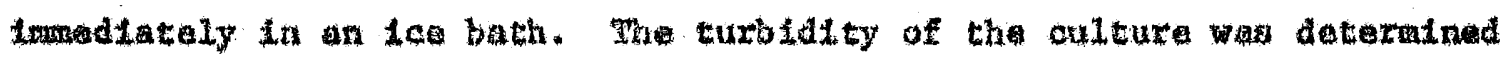
In a Bausch and tomb petronte 20 at 540 mi wavelongth. Samples of 0.1

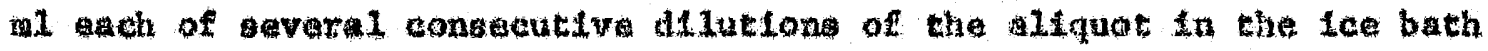

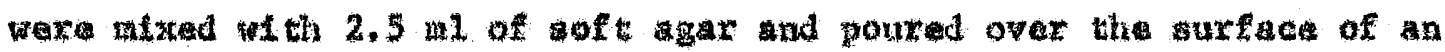
agar plate. Three plates par dLlutlon wer made. The plated were ineubated at 37 o for 48 hours. Tha viable call count and the optloal denity were corralatod (R1gure 1) and thereafter, under this atomiard sat of cultural condition, only turbldity masuraments were made and the viablo cell mubar watiated from the tandard curv (Meynell and Meyna11, 1965).

Paeperation and Agsay of Antiphaga 8ara. An antigen to allet rabbit antiphage antlods was propred fy fuer concentration and

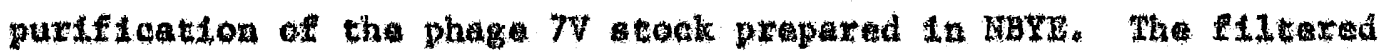

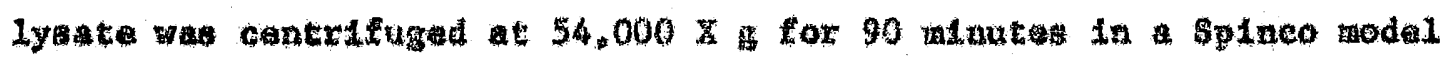

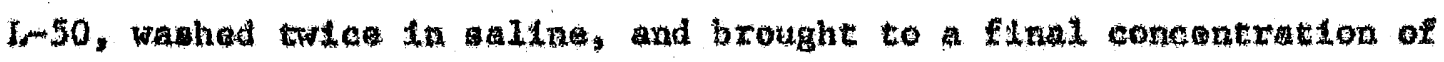

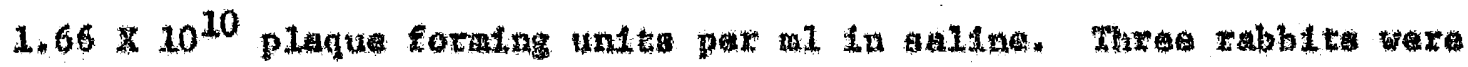
Ingactad latravenousiy w1th 0.5 ce. tally for 5 days, rased for 10 days, And then glven boostex dose of 1.0 ec. dally tat 2 daye. One 


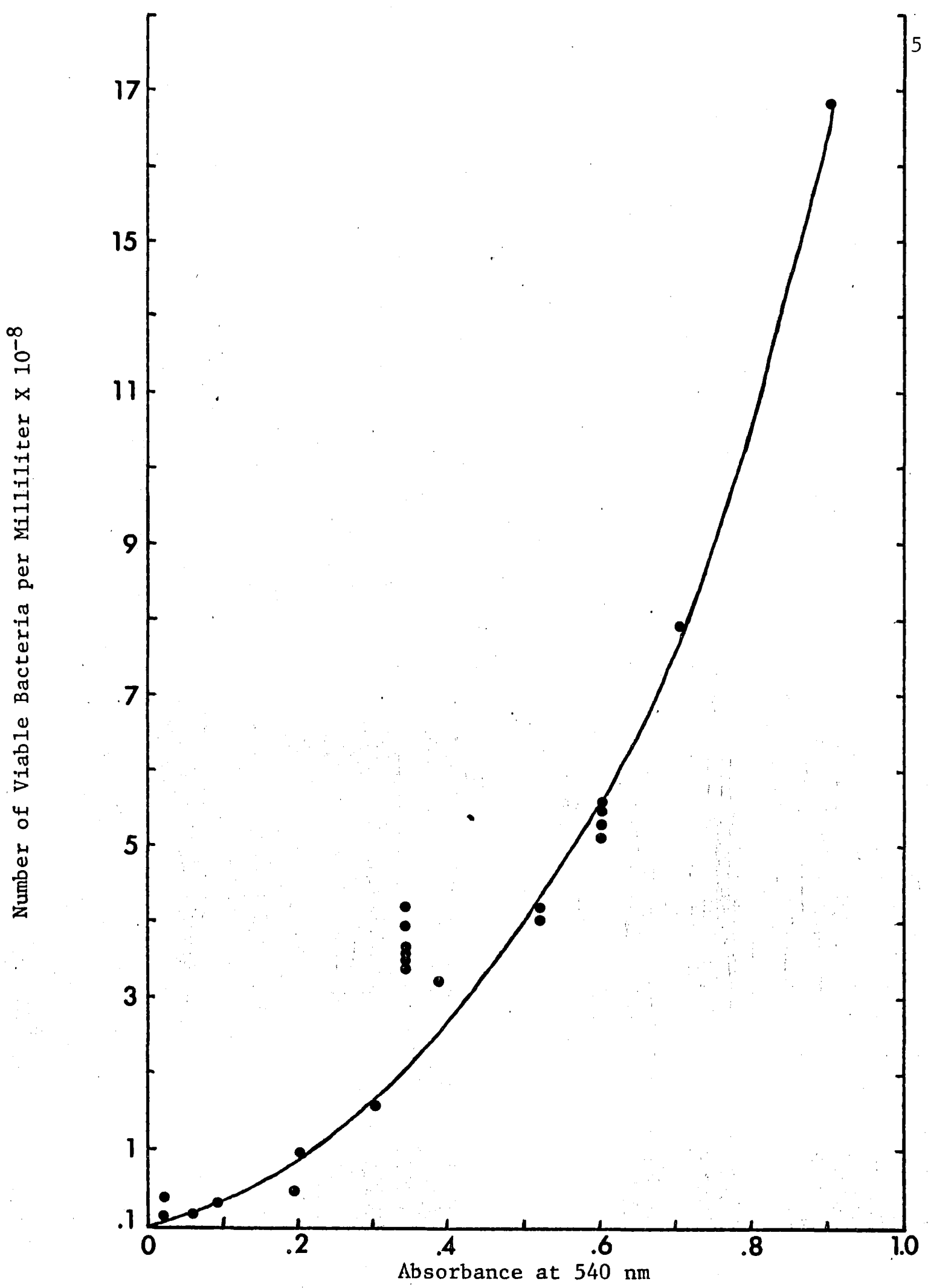

Figure 1. Growth curve of Pseudomonas aeruglnosa Ps-7 correlated with absorbance. 


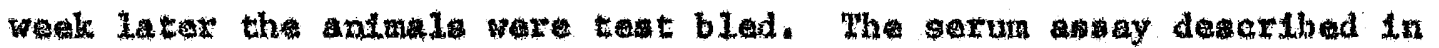
Adare (1959) tovenled a value of 115 for rabb1t 1 , 445 for rabb1t 2. and 760 Lor rabb1t 3 ; wo tha rabst tera blad out. Figure 2 19 araph of the kination of neatrallzation of phage $7 \mathrm{~V}$ by two dfferant

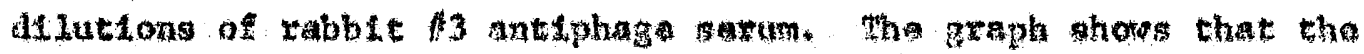

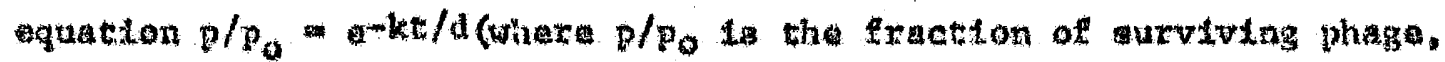

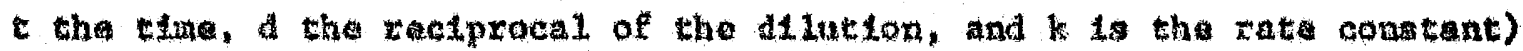
holds for the 1ractivaton of 90 pareant of the Intial phage prasent, and that the value of 1 is depeadont on the concentration of the orum.

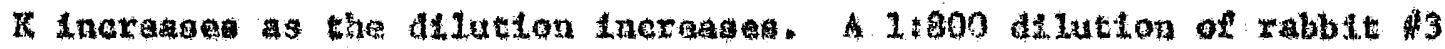

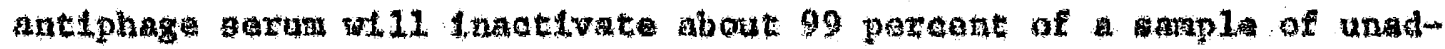
sorbed phage in 5 minutas.

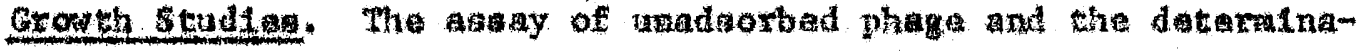

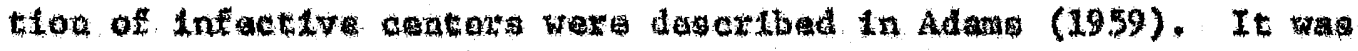
detertined from adsorption expextrenta

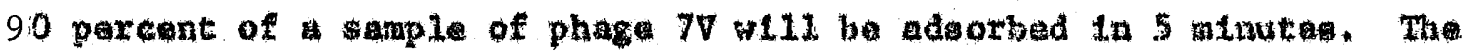
snglo- tep arowth curve and the stajle burst axpertant vere parformed according to the protocol dosoribed in Adams (1959).

Detergination of colactor requirenents tn the adsorption of phage

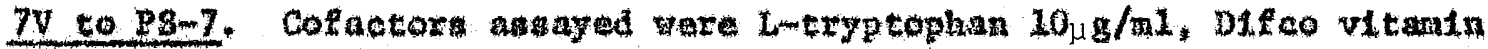
free casalno aclds $1 \mathrm{mg} / \mathrm{al}, 0.001 \mathrm{M}$ calotum tons, $.085 \mathrm{M}$ sodium Lono.

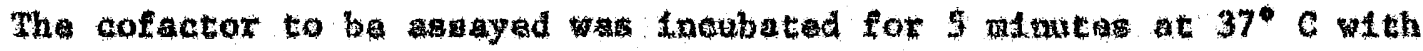

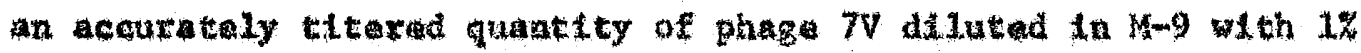

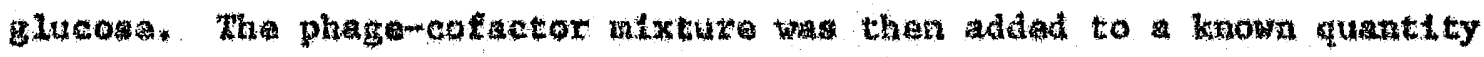

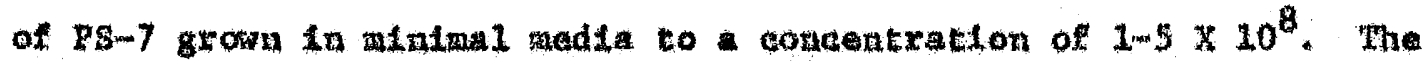

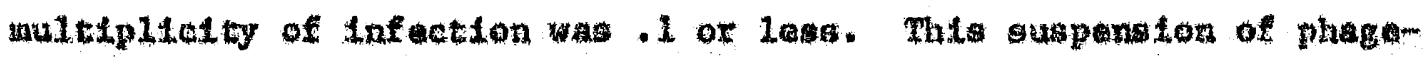




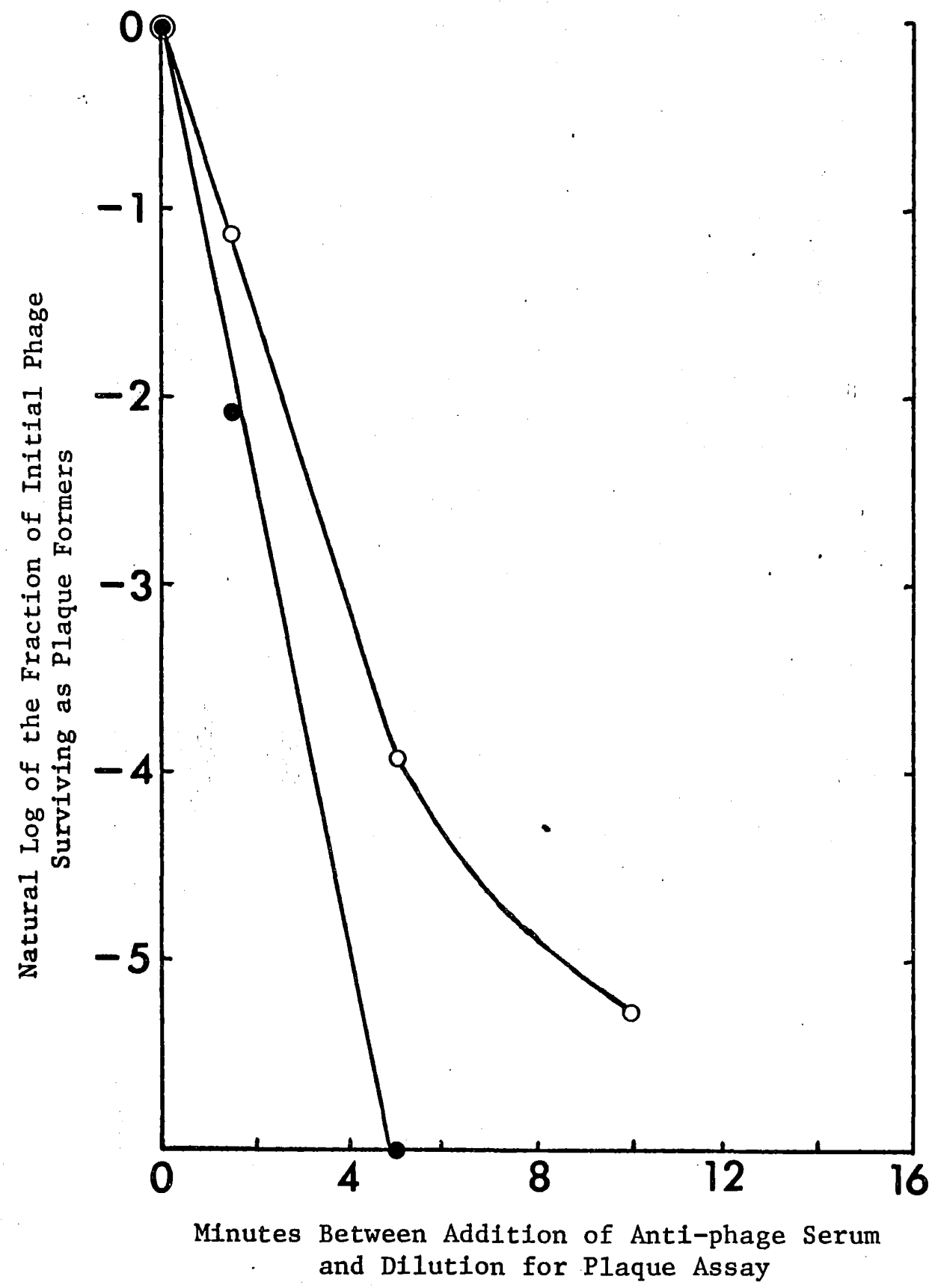

Figure 2. Kinetics of neutralization of bacteriophage $7 \mathrm{~V}$ by two different dilutions of rabbit $\# 3$ anti-7V serum. 1:100 dilution of rabbit \#3 anti-7V serum (๑), $1: 1000$ dilution of rabbit \#3 ant1-7V serum (O). 
cofactor and bacteria was Incubated for 5 minute at $37^{\circ} \mathrm{c}$ wh active meration and ample then was removed and diluted 1.100 in mintmal

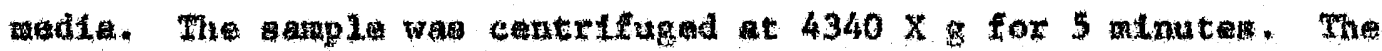
number of infective centers in the pallet and the number of unatmorbed

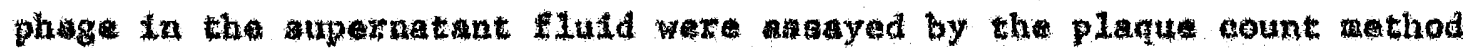
on $4-9$ wth 17 glucese agar and agrax. The entix proceduze was completed In leas than 23 minates. 
Definition of Standard Conditions. An acaurate, reproductble plaque ansay is the basis of all phage work. Rapodted asmays of phage 7V tock should give the ame titer within the value catiatically expected from the total number of plaques counted. Barly in this Invastigation the observation was mad that both quantity and quality of plaques produced was not constant. This atudy deffines a standard at of conditlong that produce: 1) a relative maxtmum of Infective centers per of stock $7 \mathrm{~V}$ phage, 2) clear, haloed plaquas at leat

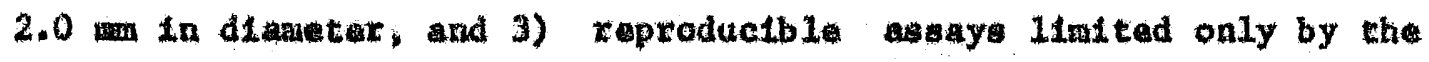
aanpling arror.

Broafenbener and Korb (1923) using phage virulent for Shlgella dygenterlae found that increased agar concentration roduced the number - plaques in the plaque count abary. B111. and Datbruck (1948) found that increased agar coneentration ald not change the nuraber of plaques but 1t did reduce the stze of the plaques, It lovident from the data In Table I that both plaque numers and plaque La were signtelcanty decreased as the agar concantration Increased due to lose of water. As Bronfanbenner and Karb postulated, the roduction in plaque forming untes is probably due to lnefficient supply of water to the host; but aduction in plaque nuber and size as the TBYE agar plates aged could also be due to the breakdown of eome of the asential bactartal abolitas.

Warshey, Kalmenson and Bronfonbrenner. (1944) found that the 
TABLE I

BFFECT OV AGE OZ NBYE PLATHS ON PLAQUE NUHBR AND PLAQUZ SIZE

\begin{tabular}{|c|c|c|c|}
\hline & \multicolumn{3}{|c|}{ Are of Agar PLutas } \\
\hline & 24 hours & 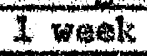 & 2 weaks \\
\hline $\begin{array}{l}\text { Plaque count } \\
\left(\times 10^{8}\right)\end{array}$ & $\begin{array}{r}107 \\
89 \\
90\end{array}$ & $\begin{array}{l}94 \\
93 \\
96\end{array}$ & $\begin{array}{l}72 \\
56 \\
57 \\
\end{array}$ \\
\hline $\begin{array}{l}\text { Avarag plaque count } \\
\left(\times 10^{8}\right)^{-}\end{array}$ & 95 & 94 & 62 \\
\hline Average laque atze & $2.0 \mathrm{num}$ & 1. 2 that & $<0.5 \mathrm{~mm}$ \\
\hline
\end{tabular}


efflelency of plateing varles with the conedatration of alectrolyta added to the agar. The long of oddur, potaselum, magnasiua, clortdo and phosphate are present in high concentration in the yeast exteret (Moyne11 and Meynd1, 1965). Therefor it 1. unlikely that they are preaent In Ilm1ting concentrations for phage multiplication. Caledum Lons have been hown to affect many oysens (Adam, 1959), and 1t may

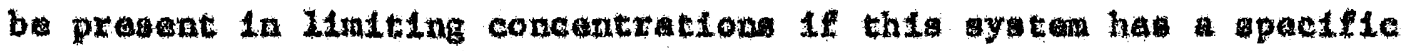

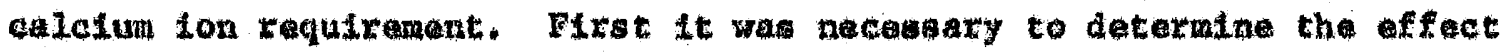
of vary1ng concentrations of calotum lons on P8-7. The factors that affect the bactertum w111 obviously affect tha mitiplication of the phage and lysis of the host. Iable II shows the result of an expertuent destgate to deteralne the foct of varylng concentrattons of calofu Lon on PS-7 and on the number of plaque forating unte per mi of stock $7 V$ phaga.

At a concentration of $10^{-2}$ M calcium ion reduces the number of viabla bateria per to approximately onemalf. However, the numbr

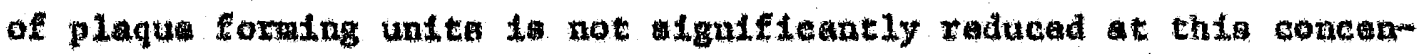
tration, but the plaque alze 1a reduced. It appeare from thio data that if there ts apacifto caleium lon requirament by this aysten, the raquirement is oupplied in adequate anount in .37 yeast extract

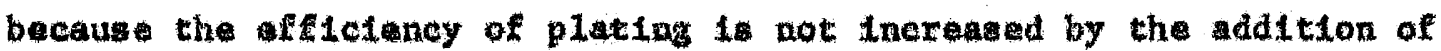
calotum In tho tasted concentrations. If the mitiplicity of Infection 1. I or loss, half the bacterta can be affected thout changtag the plaque count. The reduetion in plagu size in $10^{-2}$ cat+ further Indleate that it to the bactaxlal metabolim wheh is affected by h1gh concentrations of Cat wheh In turn affact the burst mize. 
TABLE II

TAE BFFECT OF VARYING CONCENTRATIONS OR CALCTUM IONS

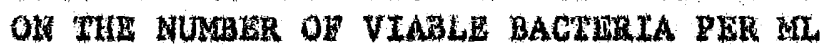

AND RLAQUE FORMIN UAITS PRR ML

\begin{tabular}{|c|c|c|c|}
\hline $\begin{array}{l}\text { Addittons to } \\
7 \% \text { Soft Agat }\end{array}$ & $\begin{array}{l}\text { Wubiber of v1ablo } \\
\text { Bacteria/rat } \times 10^{8}\end{array}$ & $\begin{array}{l}\text { Numbar of } \\
\text { PEU/a1 } \times 1010\end{array}$ & $\begin{array}{l}\text { Average } \\
\text { Plaque \$1za } \\
\end{array}$ \\
\hline No calctun & $\begin{array}{l}3.55 \\
3.40 \\
3.24 \\
3.40\end{array}$ & $\begin{array}{l}1.56 \\
1.46 \\
1.64 \\
1.55\end{array}$ & 1. 8 tant \\
\hline $10^{-5} \mathrm{y} \mathrm{Cat+4}^{-}$ & $\begin{array}{l}3.50 \\
3.30 \\
3.90 \\
3.60\end{array}$ & $\begin{array}{l}1.56 \\
1.47 \\
1.37 \\
1.47\end{array}$ & 1. $7 \mathrm{man}$ \\
\hline $10^{-4} \mathrm{cat}+$ & $\begin{array}{l}3.73 \\
3.37 \\
3.05 \\
3.36\end{array}$ & $\begin{array}{l}1.64 \\
1.52 \\
1.51 \\
1.56\end{array}$ & 1. 6 and \\
\hline $20^{-3} \frac{\mathrm{hat}}{\mathrm{a}} \mathrm{Cat}$ & $\begin{array}{l}3.33 \\
2.64 \\
4.10 \\
3.36\end{array}$ & $\begin{array}{l}1.52 \\
1.42 \\
1.27 \\
1.40\end{array}$ & $1.6 \mathrm{man}$ \\
\hline $10^{-2}$ Catt & $\begin{array}{l}1.56 \\
1.28 \\
1.34 \\
1.46\end{array}$ & $\begin{array}{r}1.43 \\
1.35 \\
1.30 \\
1.38\end{array}$ & $0.5 \mathrm{~mm}$ \\
\hline $10^{-1} \mathrm{MCat}+$ & 0 & 0 & 0 \\
\hline
\end{tabular}




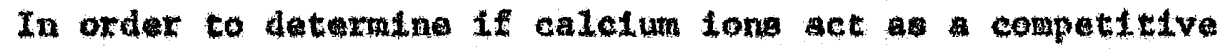
Inhtbitor of tagneshum at concentrations of $10^{-2}$ and higher, this

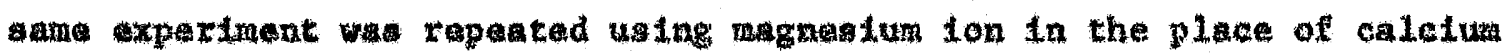
10n. The resulte too were the At concentrotion of $10^{-2} \mathrm{M}$

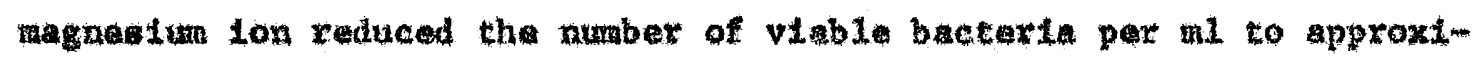
wately omethalf, whlle the numer of plaque forming untwa was not atg atficantis raduced at thid concentration.

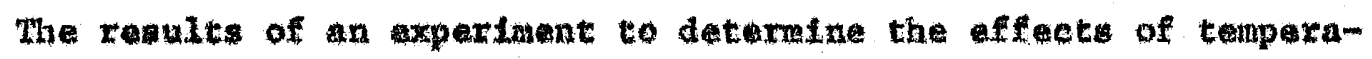
ture and dilution on the number of plaque forming unt gumartzad In Tablo IIT.

TABLE IXI

TIB EEYICT OP TEMPLRATURE AED DTLUTTON ON THE PLAQUR DORMTE ABILITY OF A STOCK 7V PUACE IN WBYE

\begin{tabular}{|c|c|c|}
\hline $\begin{array}{l}\text { Temperature } \\
\text { and Thase }\end{array}$ & $\begin{array}{l}\text { Und lluted Stock } \\
7 V \text { Phage/ni }\end{array}$ & $\begin{array}{l}\text { Stock 7V } \\
\text { Phase, DL1uted } 10^{-7}\end{array}$ \\
\hline $\begin{array}{l}\text { Rafr } 18 \text { arated } \\
\text { for } 24 \text { hours }\end{array}$ & $\begin{array}{l}\frac{121}{124} \\
\frac{125}{123} \times 10^{8} / \mathrm{sin}\end{array}$ & $\begin{array}{l}117 \\
126 \\
\frac{124}{122} \times 10^{8} / \mathrm{ml}\end{array}$ \\
\hline $\begin{array}{l}\text { Roow terpexature } \\
\text { for } 24 \text { hours }\end{array}$ & $\begin{array}{l}154 \\
175 \\
\frac{160}{163} \times 10^{7} / \mathrm{m} 1\end{array}$ & $\begin{array}{l}46 \\
41 \\
\frac{39}{42} \times 10^{8} / \mathrm{m} 1\end{array}$ \\
\hline
\end{tabular}

Reproductble plaque count asmays could be obtained from a single tube, If the diluted gtock $7 V$ phage was refrigerated Imediately after dilution. Two weks after the intelal oxpertment, reproductble plaqua count assaya were obtalned frow the refrigerated diluced stock $7 V$ phage. 
Wher diluted atoek $7 V$ phage was held at roon temperature or $37^{\circ} \mathrm{C}$ overnight, ther was ome inetivation of the phage.

Studieg of the Adsorption of thege $7 V$ to PS-7. Phage adsorption can be described by the equation -ap/at a KBP were I the numbar of phage particla rematiato after time $t$, the concentration of bacterial cells in the adoorption wixture, and $k$ is the adsorpeton rate contant axpresead in $m 1$ per minute (Adans, 1959). This equation states that the rate of adsoxption (the slope of the curva) 18 dependent upon the concentrations of becteria and bacterlophage in the raaction mixture, and that the fre phage decrese with the time allowed for admorption. The adsorption of 95 percent of the phage population obey the kinetios of this reaction (Adata, 1959).

The kinatles of the adeorption of phage $7 \mathrm{~V}$. to 1 ts host PS-7 are show lu F1gure 3, graph of a typleal adsorption experiment in which unadsorhad phage mere nasured.

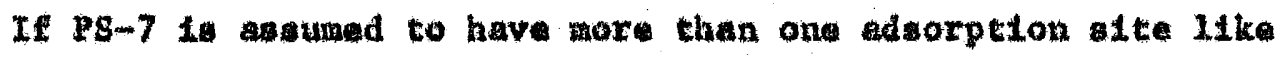
the colfphage T-2 (Watoon, 1950) and te the multiplicity of Infection 1s low (In this case. .2), the bacterial concentration can be conatdered constant. The reaction becomes paeudo-firat ordar reaction. The logarithin of the fraction of unadeorbed phage versus time should then give atralght IIne which 111 not flaten out becaua the bacterial auffacs cannot bacone aturated. As infection proceeds, the bacterial coll way be changed In ouch way that 1 ts velocity constant is no Ionger the same and, thexefor, as shown In figure 3 , the veloctty constat would be contantly changling. F1gure 3 may also be the 114ustration of adeoxption of phage to 1 te host 9 s-7 by two distinct 


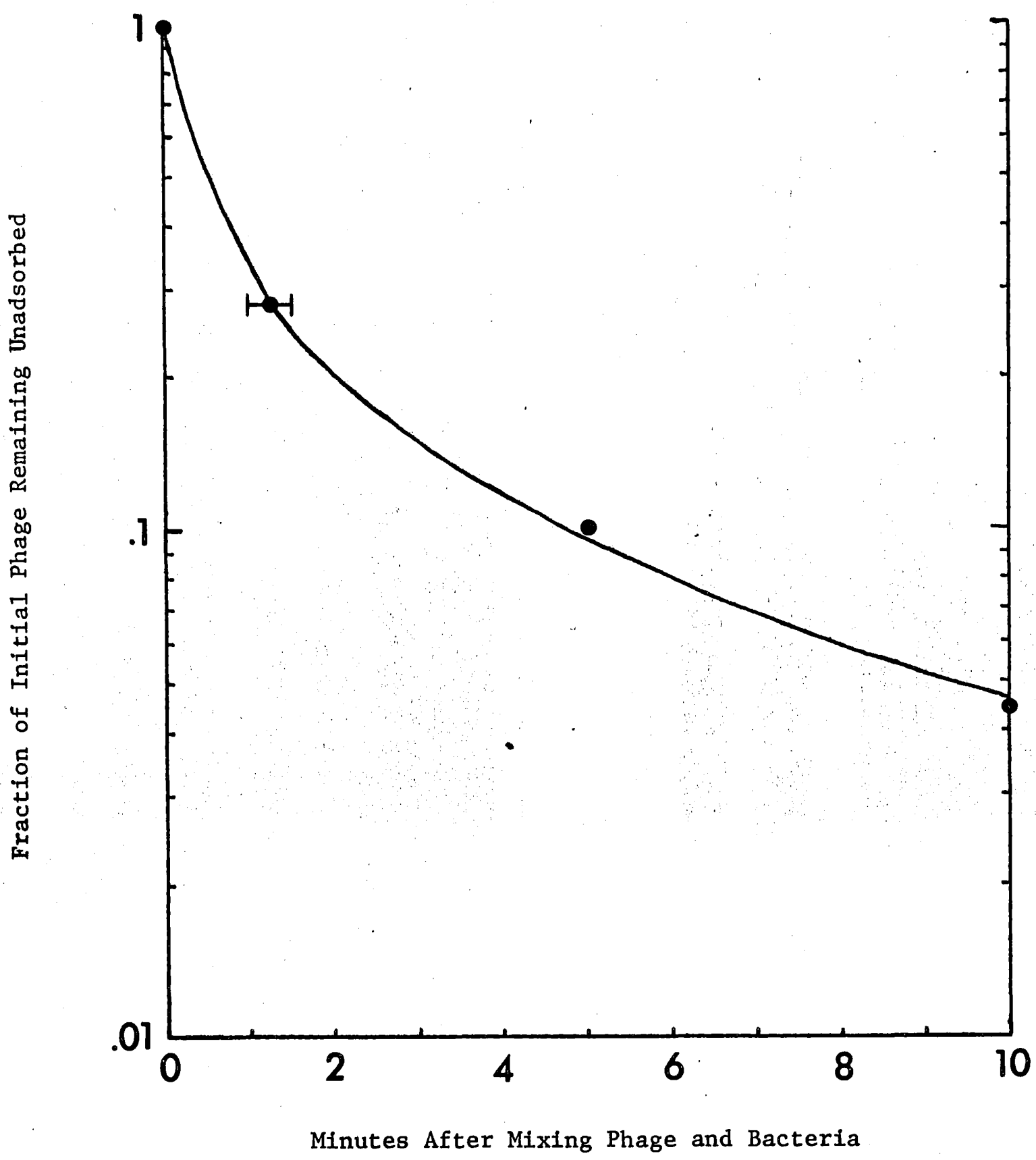

Figure 3. Kinetics of the adsorption of phage $7 \mathrm{~V}$ to its host Ps-7. 
populations of phage with different adoorption rates. The data in rable IV points out the fact that the equation, - dp/dt - KBP, does not take Into account blolog1cal propartite of phage or bacterta such a tha physiologlcal sate of the bacterial cella.

\section{TABLE IV}

KCMETICS OF THE ADSORPTION OR BACIERTOPEAGE 7V TO ITS EOST PS -7 AT VARTOUS DBWSTIES OF BACTERIA

AND BACT HRTOPHAGT

\begin{tabular}{|c|c|c|c|}
\hline & $\operatorname{Exp}, 1$ & Exp. & Exp. 3 \\
\hline Phage concentration & $8.0 \times 10^{6} / \mathrm{ml}$ & $8.0 \times 10^{6 / m 1}$ & $9.5 \times 10^{6} / \mathrm{m} 1$ \\
\hline Bacterial cone. & $6.25 \times 10^{3} / \mathrm{ml}$ & $1.5 \times 10^{7} / 21$ & $1.7 \times 10^{8} / \mathrm{m} 1$ \\
\hline $\begin{array}{l}\text { Peroent Inttial } \\
\text { phage ndeorbed in } \\
5 \text { inditutes }\end{array}$ & $88.10 \%$ & $89,75 \%$ & $96.78 \%$ \\
\hline $\begin{array}{l}\text { Adsorption Rate } \\
(-d p / d t)\end{array}$ & $-2.41 \times 10^{6}$ & $-1.43 \times 10^{6}$ & $-1.79 \times 106$ \\
\hline $\mathrm{m} 1 / \mathrm{min}$ & $.63 \times 10^{-9}$ & $3.034 \times 10^{-9}$ & $3.06 \times 10^{-9}$ \\
\hline
\end{tabular}

In the first two experimente, the concentration of phage is constant but the bacterial denst ty is higher 1a 2xp, 2 ; the tato of adaorption In Experinent 1 should be greater than the rate In Experiment 2. But 1t I. not, Schlestngex (Adans, 1959) howed that the admorption rate of phage to 1 iviag bactexta 182.6 thes faster than to heat k111ed bactexta. Since the PS-7 cells were In the atationary phase In Ixpertment 1, this may eccount for the reduced adsorption rate, The rate constant, *k, revealo that for cello in the early logrialtide phase, the valoctty of adorption proceeds at rate 38 times greatex than for 
Qdis in the atationary phase.

Under optial condition the adsorption of phage $7 V$ to 1 ts hoa procede at a rapld rate. Ninety percent of the Inttal phage ax adgoxbed in 5 stinutes.

Whe optrad conditlons for adsorption depand not only on the condition of the bactarlum, both phymeally and blochmileally, but also on enviromental factora. Ruck, Garen and c1ino (1951) concluded from their otudy of the eftect of salt on collphage adsoxption thet the first atep in phage adaorption ts the tablishnent of electrotatic bonds between phege and batertum. The data in Table $V$ wows the ragults of an exportment destgned to detarmina the ffect of .001 M calcium chloride and .085 4 sodium chlortde (1oxic trength .003 and .085 respectively) on the adsorption rates of phage $7 V$ to tta hast PS-7. The veloctty constant, $K$, to used to characterta the morotion rates.

\section{TABLE V}

LFPECT ON ADSORPTION RATE CONSTANS OF

CALCIUM AND SODTUM IONS

Additions to Nart

None

$0.085 \mathrm{MaCl}$

$0.001 .0 \mathrm{acl}_{2}$
Adaorption Rate

Constant $X$ ia al/oia

$$
3.06 \times 10^{-9}
$$

$1.05 \times 10^{-9}$

$1.00 \times 10^{-9}$

It to evidate from tha table that the optimal walt concentration for phage $7 \mathrm{~V}$ adsorption is found in the ange bacause phage $7 \mathrm{~V}$ is 
adsorbed wth maximal veloetty to 1t host PS-7 In NBY\&. The addition of .085 sodium chlortde or .001 $M$ calctum chlortde raduced the adsorption rate constant indieating that adsorption rate is a function of Lonfe concentration. Since the voloct ty constant is the same for both sodium and calatum 10ws, the setion of the lons must bon nonapedfic interforeme with the electostatio bonds between phag and bacterium,

A corparison of the plating afficlency of phage $7 \mathrm{~V}$ under varlous condtclons revealed that when the platine bacteria vexe grown la mindmal media, the number of plaques formed on WBYE $+.5 \% \mathrm{NaCl}$ agar wa higher than the number of plaques formed on mintmal agar (Tabl VI). To rule out the posulbility that the plating bacterie grown in minimel madia were so poorly nourtshed that they ware unabl to support the wultiplication of adsorbad phage on minimal agar, plating bacterta were grown in WBYH $+.5 \%$ NaC1 to concentration of $1-5 \times 10^{8}$ becteria per m1, washod twice in mintual sadia, and resuspended to their origtnal volume in minal media. It Is apparent from Tabla VI that the effect

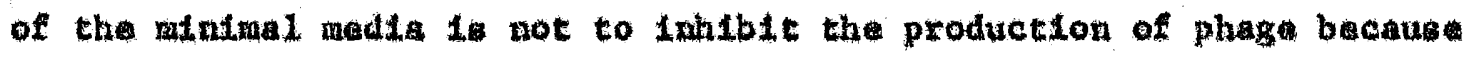
of poor nutritton of the bactartal host.

Anderson (1945) worktng wh the $\mathrm{T}$-evan phages of $\underline{\mathrm{g}}$ coll damon-

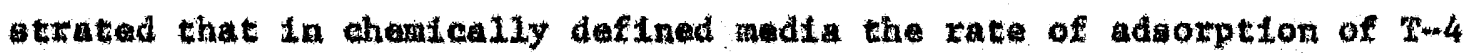
nutants to their host was axtremely low compared to their rate of adeorption in a complete media consisting of amino actds, purines, pyrtmidines and vitantins, He further demonstrated that the addition of Exyptophan to T-Ax11n aynthete media of the adaltion of tryptophan

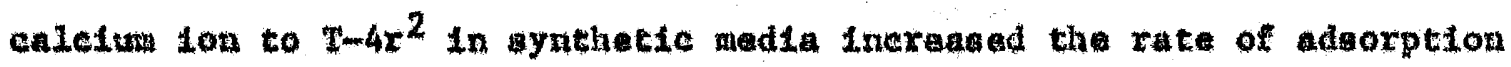


TABLE VI

COMPARISOA OF PLAQUE COUNT ABSAT ON COMLETE AMD CHAMTCALLY DEFTMED MEDTA

\begin{tabular}{|c|c|c|c|}
\hline $\begin{array}{l}\text { Crow th Kadka } \\
\text { for strata PS-7 }\end{array}$ & & $\begin{array}{l}\text { Minina 1. Agax } \\
\text { P Lateas }\end{array}$ & $\begin{array}{l}\text { NBYg } .57 \text { Yacl Agar } \\
\text { Platas }\end{array}$ \\
\hline \multirow[t]{3}{*}{$\begin{array}{l}\text { Liquid mintmal } \\
\text { media }\end{array}$} & & $\begin{array}{l}7.2 \times 10^{9} \\
7.0 \times 10^{9}\end{array}$ & $\begin{array}{r}9.9 \times 10^{9} \\
8.7 \times 109 \\
11.2 \times 10^{2} \\
\end{array}$ \\
\hline & & $7.1 \times 109$ & $9.9 \times 10^{9}$ \\
\hline & $\begin{array}{l}\text { avarage } \\
\text { plaque atze }\end{array}$ & 3. 3ara & $2,8 \operatorname{man}$ \\
\hline \multirow[t]{3}{*}{$\mathrm{NBYE}$-5\% $\mathrm{KaCl}$} & & $\begin{array}{l}1.11 \times 1010 \\
1.12 \times 1010 \\
1.07 \times 1010\end{array}$ & $\begin{array}{l}1.13 \times 1010 \\
1.14 \times 1010 \\
1.11 \times 1010\end{array}$ \\
\hline & & $1.08 \times 1010$ & $1.13 \times 1010$ \\
\hline & $\begin{array}{l}\text { average } \\
\text { plaque 1ze }\end{array}$ & $2.5 \mathrm{man}$ & .55 to $3.15 \mathrm{~mm}$ \\
\hline \multirow{3}{*}{$\begin{array}{l}\text { NBYE } .5 \% \text { NaCl } \\
\text { wahad and } \\
\text { resueponded in } \\
\text { matuml podia }\end{array}$} & & $\begin{array}{l}6.5 \times 109 \\
3.7 \times 10^{9} \\
4.3 \times 109\end{array}$ & $\begin{array}{l}8.0 \times 109 \\
6.9 \times 10^{9} \\
6.5 \times 10^{9}\end{array}$ \\
\hline & & $4.8 \times 109$ & $7.1 \times 109$ \\
\hline & $\begin{array}{l}\text { Evarage } \\
\text { plaque lze }\end{array}$ & 3. 3ting & $2.8 \mathrm{nnm}$ \\
\hline
\end{tabular}


to that observed in the complat media.

Iable VII how the rosults of expertments designed to detarmatme the ffect of collactors on the adaorption of phaga $7 \mathrm{~V}$ in chemically deftned mintme 1. media.

Thaxe wust be sone factor preant In MBYE, but absent in the minimal media, which Incrases the veloctty of the adeorption raction. Thin could be an organic cofactor or it could bo apectic ion requirement or both. The addition of casamino actas and tryptophan increases sonewhat the veloeity of the reacton, but the maxtoun veloctcy observed in ingy is not attalned. The addition of tryptophan ox tryptophan + calcium lons has no effect on velocity of the adsorption reaction In minimal modia as detorminod by the menarement of 1nfective centers. Neasurement of unadoorbed phage in thase syatens Indicates that adsorption of phage to ps-7 is taking place. Tryptophan or

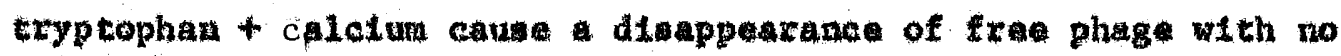
corrasponding incraase in infectve centera. Calciun tons, .001 $M$,

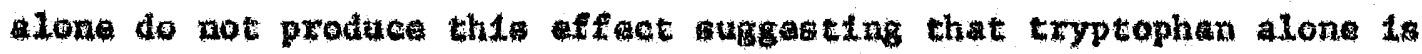
respoutbla for the apparant 1ncrease in the valoct ty of the reacton. It seew that the phage is either Injecting Ite BNA Into the anviroment or after Infecting its DNA Into the host, the host bahaves as if non-

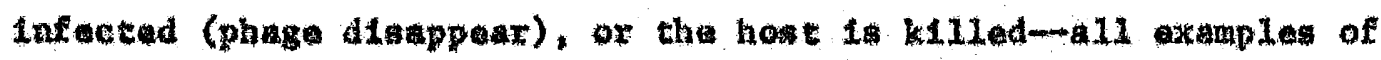
abortive Infection (Iwoff, 1953 ).

Support for this view is the observation that under optinal condtton In WBYg, the Input of phage 1s nevar aqual to the numbar recov-

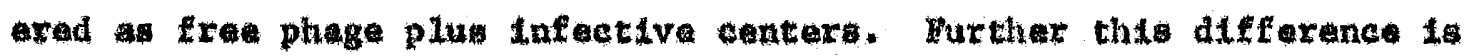
gxeater than can be accounted for by sampling arrox. 


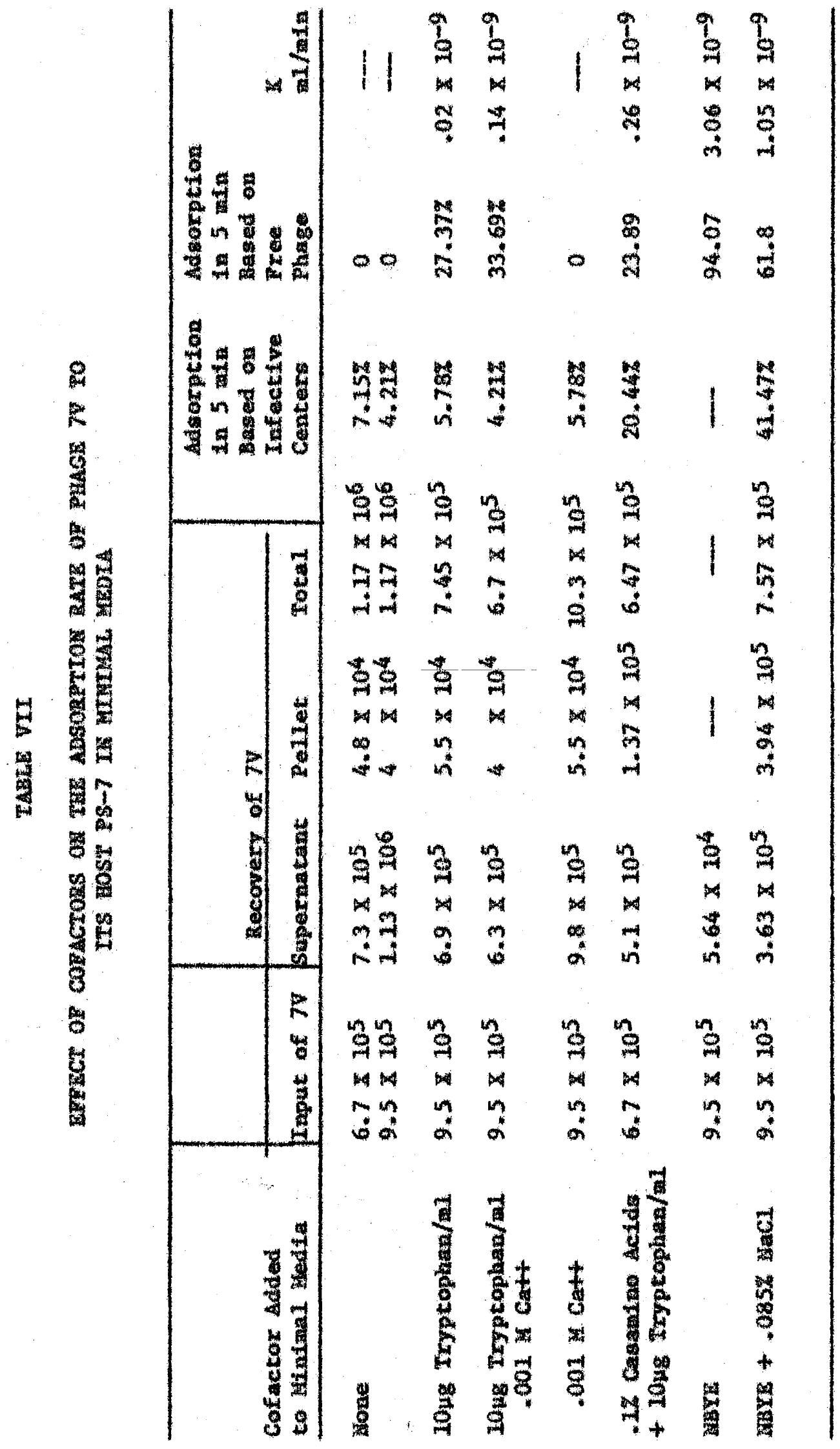


These same results inght also be observed if more than one phage had adsorbed to a bacterial cell. Since the multiplictty of Infection was less than 0.002 , only 8 percent of the bactectal population could have been multiply lafected.

Since tryptophan was in contact with PS-7 for only a short time pxlor to measurenento for free phage or infective centers, thls helped to eliminate the posalbility that tryptophan was metabolized to a prom duct which Inhtbited phage adsorption (Delbruck, 1948).

It sems Iikely that these cofactord are necessary for adsorption and not for multiplication, since overnight lysates of PS-7 yield a high titer of phage 7 .

Deternination of growth characteristies. Iigure 4 is a typical one-gtep growth curve obtained following InEection of PS-7 with phage $7 V$ In NBXE; multiplialty of infection was 0.003 . The latent perlod is 23 minutes and the rise partod 10 minutes. Burst s1ze determined in this manner averaged 7 . Thlo is quite low; an experiment to detarmine the burst size more accurately revealed an average burst aize of 36 . 


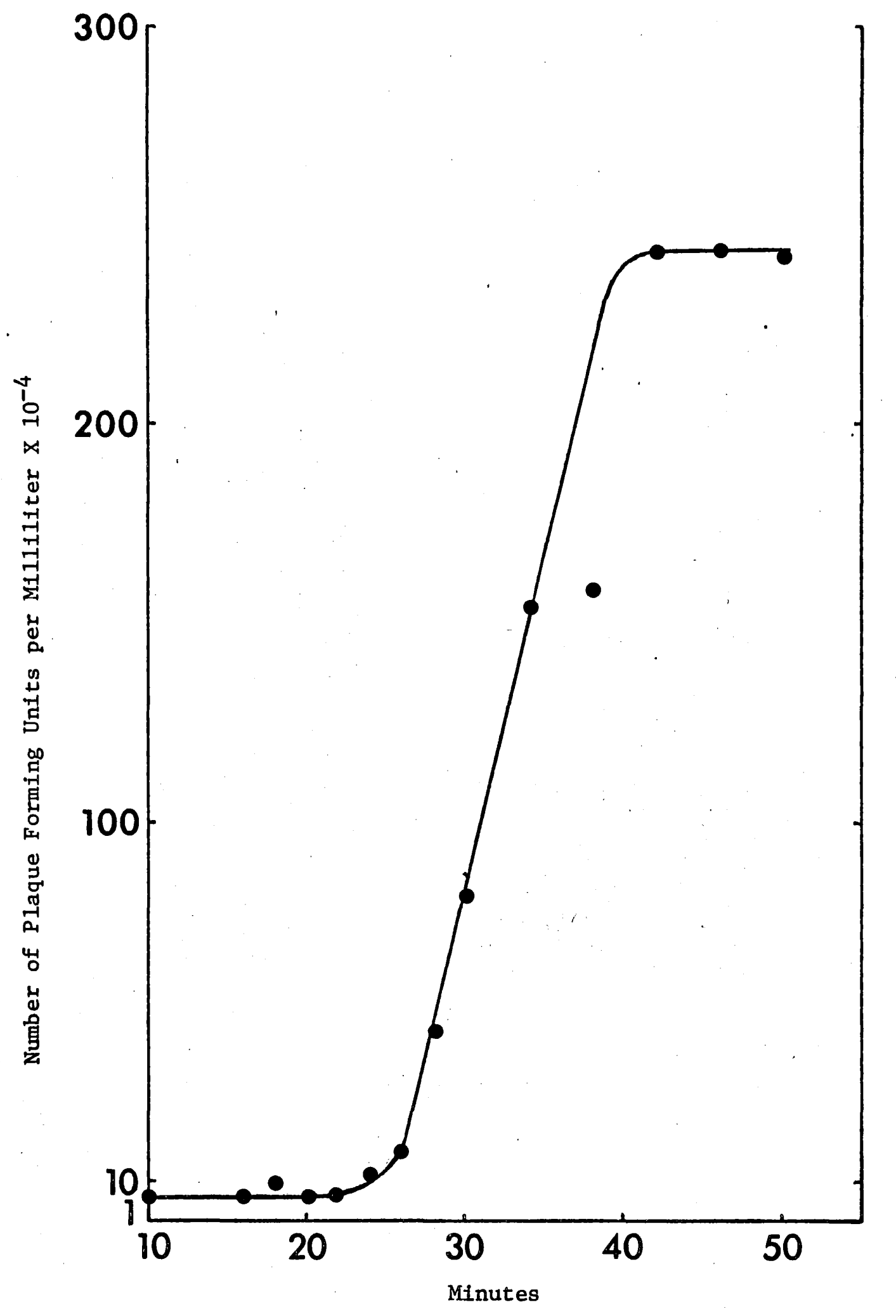

Figure 4. Single-step growth curve with phage $7 \mathrm{~V}$ on its host PS-7 in NBYE. 
DI8CUSSION

S1nce thi la a new bacterlumbacteriophage ayeten, a ctandard set of growth condthlons ast be defined. In tha 11tarature, "standard condttons" moans thet exportments are carrled out ueling log-phase bacter1a growing th mertent broth plue $0.1 \mathrm{M}$ sodium chloride at $37^{\circ} \mathrm{C}$. Thene condittons Iaply recogntition of the faportance of nutritton and phystologieal state of the bacterial call to the production of the anatiaum number of plequa forming unde from a glvan tock phage. these

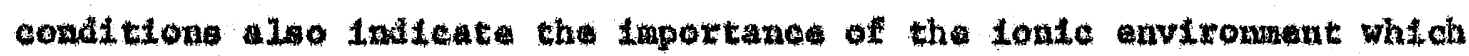
1e the cost cratal factor in phag admoxption (Adaas, 1959).

Ions an be requerad In all three tages of phage growth. Puck At 1. (1931) postulated that the etret tap in phage adsorption is the astabliahment of liactrostatte boxds. The requirement for 1ons In thio rasetion would be nompactic. Delbruck (1948) demonetrated

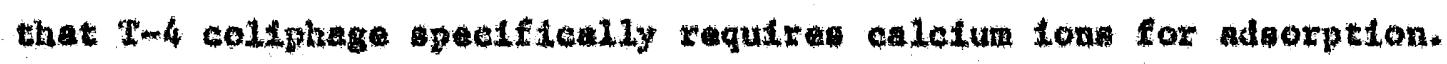

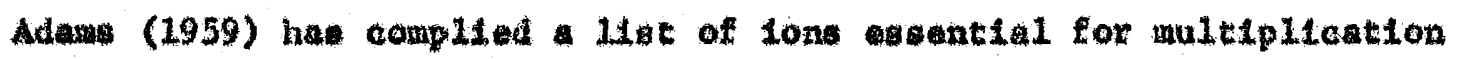

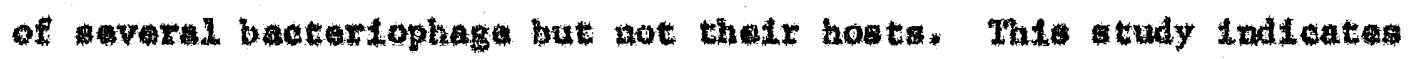

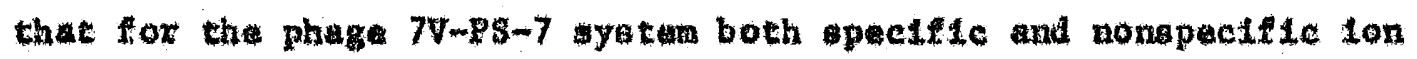

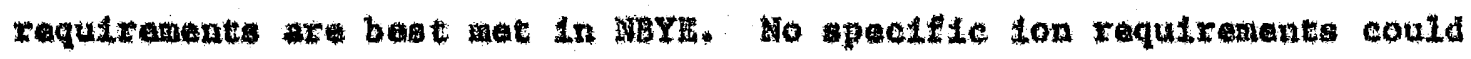
be demons trated:

Standard conditiono for phage $7 V$ and 1tre host $25-7$ aro defined as:

1. Freah NBYE or MBYE agar used for the growth medtun

2. NBYR of buffared alits alution used for the diluent

3. phyelologteally young cells in the logmpare betwean 1-5 $\times 100$ bacterla por m1

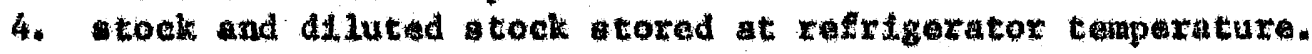


Under tandard conditione, the number of plaquas produced should be Eunction of the number of phage adgorbed, if the muletplidetty of 1.tuction If las than one. Howaver, the number of umadmotbed phage

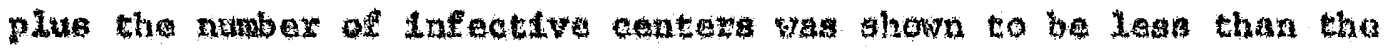

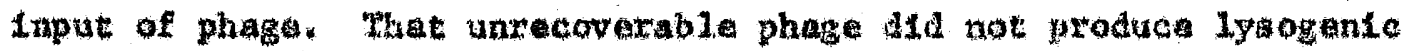
clonga was shown by the obarvation that clar, haloed plaquas ware condstanty formed, The nature of the bortive Infection was not Investigeted, but it vouza be worthohile to detormtne the fate of the

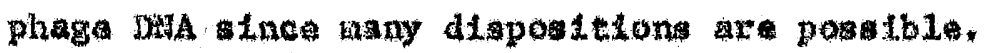

The lizo of the plague produed undex optral conditions is a tunetion of the velout of adorption as we11 as the burge ata and Letent pertod. Delbruck (1940) desertbed plaque fornation as a race between the nultiplication of phage and the reow th of the bacterta,

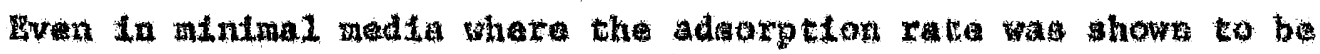
axcremely low, the phage nould have time to sultiply batore mont

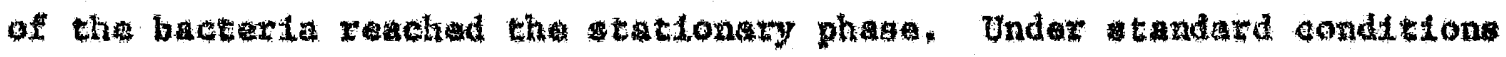
the latent partod to contant at 23 numuces and the average burst atse Is also constat although sail. Thorefore, the atwe of the plaques produced appers to be controllad by envixonontal condstione, while the relative number of plaques produced lo a charatertatic of the phage-bactertu yatem.

Hally it should be noted that when the plaque olze varian from 2.5 to las than 0.5 wh on a crowded plate, many of the maller plaques may be wisued. Therefore, the quantety of plaques may remin relatively constant but apper to change drastichily becnuse of the qualicy of the plaquer. 


\section{LITHANAR CITED}

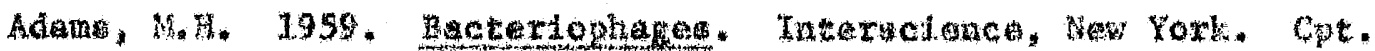
II, III, $x_{*}$, aplendix.

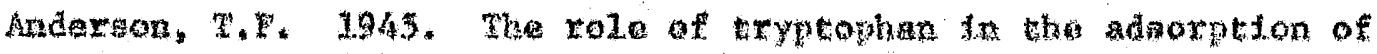

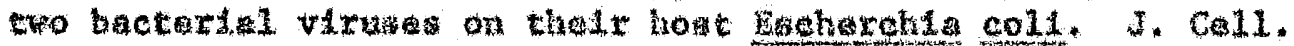
Comp. Atys $101 * 25: 17$.

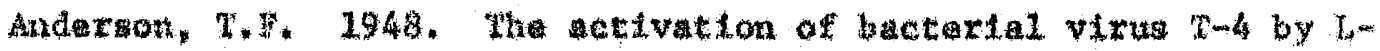

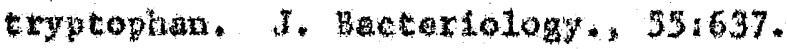

Bronferbreand, S.J. and 0 .

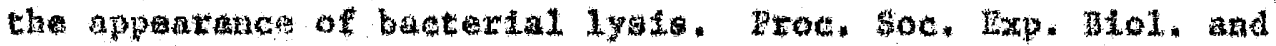
Hed, 21:315.

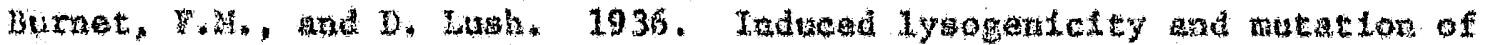

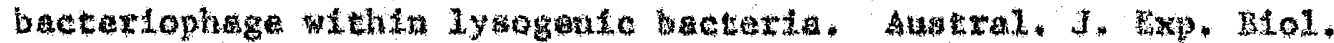
ked.

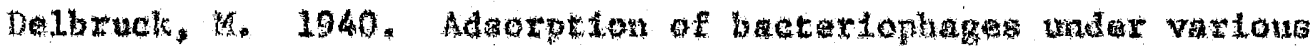

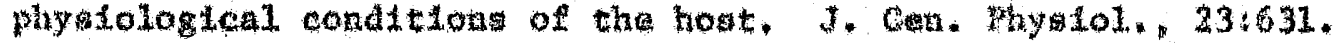

Deloruck, $x$. 1940. The growth of battariophage and lysis of the host. J. Gen. Mys Lol, 23:643.

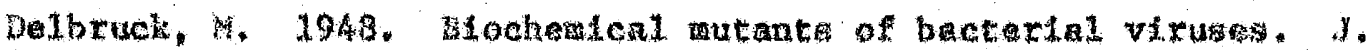
Beterio1., $56: 1$.

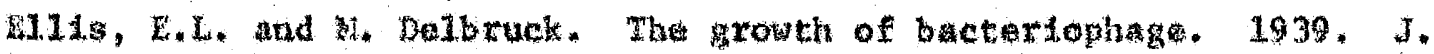

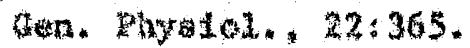

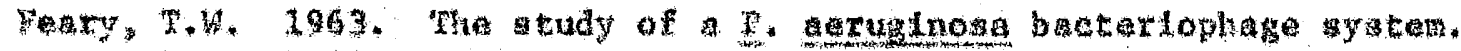

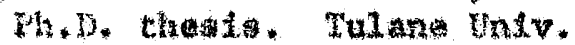

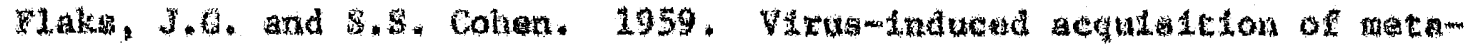
bolle function. I. Hol. Chew. 234:1501.

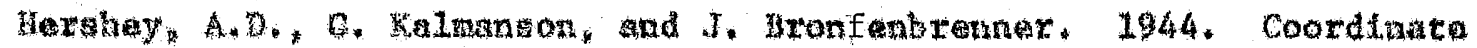
affects of alectrolyt and axthody on tnfectivity of bacterion phage, J. Inraun, 481222.

Mook, A. J. Hol. Gram., 1965:241.

Lwoff, A. Lysogeny, 1953. Bactar101, Pev, 17269, 3. 319. 
Meyna1, 0.6. and 11nor Hetne11. 1965. Theory and practed In

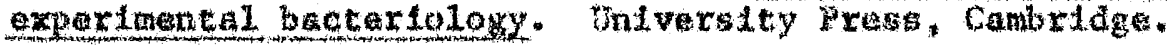

Fuck, T. ateactiment to host cella. I. The role of lone th the prinary

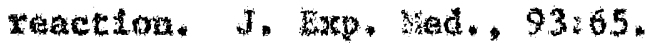

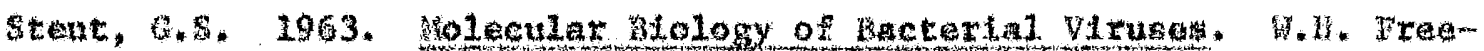

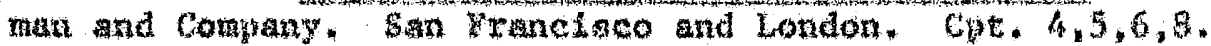

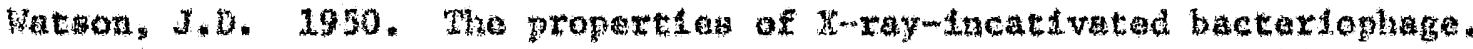

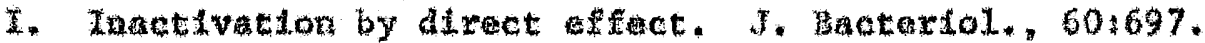

